\title{
Infusing reflective practice in eLearning courses - Can widgets help?
}

Citation for published version (APA):

Verpoorten, D., Westera, W., \& Specht, M. (2011). Infusing reflective practice in eLearning courses - Can widgets help? International Journal of Technology Enhanced Learning, 3(1), 93-109.

https://doi.org/10.1504/IJTEL.2011.039066

\section{DOI:}

10.1504/IJTEL.2011.039066

Document status and date:

Published: 01/01/2011

Document Version:

Peer reviewed version

Please check the document version of this publication:

- A submitted manuscript is the version of the article upon submission and before peer-review. There can be important differences between the submitted version and the official published version of record. People interested in the research are advised to contact the author for the final version of the publication, or visit the DOI to the publisher's website.

- The final author version and the galley proof are versions of the publication after peer review.

- The final published version features the final layout of the paper including the volume, issue and page numbers.

Link to publication

\section{General rights}

Copyright and moral rights for the publications made accessible in the public portal are retained by the authors and/or other copyright owners and it is a condition of accessing publications that users recognise and abide by the legal requirements associated with these rights.

- Users may download and print one copy of any publication from the public portal for the purpose of private study or research.

- You may not further distribute the material or use it for any profit-making activity or commercial gain

- You may freely distribute the URL identifying the publication in the public portal.

If the publication is distributed under the terms of Article 25fa of the Dutch Copyright Act, indicated by the "Taverne" license above, please follow below link for the End User Agreement:

https://www.ou.nl/taverne-agreement

Take down policy

If you believe that this document breaches copyright please contact us at:

pure-support@ou.nl

providing details and we will investigate your claim.

Downloaded from https://research.ou.nl/ on date: 26 Apr. 2023 
Infusing reflective practice in eLearning courses Can widgets help?

\title{
This is the pre-print of:
}

Verpoorten, D., Westera, W. and Specht, M. (2011) 'Infusing reflective practice in eLearning courses - can widgets help?', Int. J. Technology Enhanced Learning, Vol. 3, No. 1, pp.93-109.

\begin{abstract}
The paper investigates the potential of using widgetsbased reflection amplifiers in e-learning courses. Reflection amplifiers are structured opportunities for students to examine and evaluate aspects of their learning experience. The paper deliberately chooses a non technical viewpoint. It takes the teachers' voices as a starting point. The study reports the results of a survey that asked Open Educational Resources course creators about their opinions on different types of reflection amplifiers. The outcomes demonstrate that several reflection techniques are recognized and acknowledged by these practitioners as being of relevance for their courses. Yet, practical application in their courses is quite rare. Results of the survey are subsequently used to inspect possible contributions of widgets technology to the implementation and dissemination of a selection of reflection techniques. The set-up of an experiment intended to test feasibility and relevance of widgets-based reflection amplifiers is eventually outlined.
\end{abstract}

Keywords: widgets; reflection; eLearning; Open Content; Open Educational Resources; OER; metacognition; metalearning; mashups; Personal Learning Environments; PLE, teachers' voice; Technology Enhanced Learning; TEL.

\section{Widgets for reflection}

This article is positioned at the cross-section of an emerging Internet technology (Web 2.0) and a pedagogical trend (the promotion of reflection and meta-learning). It precisely questions the educational potential of a junction between a new breed of software applications called widgets with the call for more reflection in learning.

\subsection{Reflection}


Reflection is an active process of witnessing one's own learning experience and evaluating it on different aspects. Reflective practice (and akin notions like "learning to learn", "meta-learning" and "meta-cognitive development") is a significant topic in education and training (Schön, 1983). Meta-analysis (Hattie, 2009; Marzano, 1998; Wang, Haertel, and Walberg, 1990) rank reflection amongst the strongest influential factors of learning. Its potential concurrently applies to the enhancement of the domain-specific knowledge and the knowledge about the self-as-a-learner. Reflection is claimed to promote deeper and more effective learning both in regular classrooms (Watkins, 2001) and in eLearning settings (Means, Toyama, Murphy, Bakia, \& Jones, 2009). It is generally acknowledged that stimulating deliberative practice will prepare knowledge workers to cope with requests for new knowledge acquisition and ongoing personal development in the information society (Rychen \& Salganik, 2003; European Commission, 2006). However, despite the alleged importance of reflection, current instruction shows a shortage of training for this generic skill (Carnell, 2005; Claxton, 2006; Csapó, 1999).

\subsection{Widget}

The term "widget" refers to a miniature Web application performing a single task and displaying a very clear and appropriate graphical style (Wilson, 2008). A widget provides a single interaction point for the visualization and direct manipulation of a given kind of data (Guy Widget, 2009). Typical examples would be widgets that show today's weather forecast, upcoming birthdays or information stocks, designed for the desktop, the Web or the mobile. Personal learning environments (PLEs) are already taking advantage of widgets (Attwell, 2007). The widgets technology seems to be available to eLearning whilst it is not yet clear how it can best be used within a formal context of instruction and what its specific technical, pedagogical, organisational advantages would be.

\subsection{Widgets in the service of reflection}

Making widgets available that are dedicated to supporting reflection in elearning courses may help increasing the quantity, quality and persistence of reflection on learning. In this respect, an increased availability of "widgets for reflection" would nicely align with the call for more reflective practice in schools.

This paper opens a line of inquiry about such "widgets for reflection", defined as widgets designed to prompt and support clear, small and single 
Infusing reflective practice in eLearning courses - Can widgets help?

reflection-related tasks occurring prior, during or after a formal learning sequence. The paper begins, in the next section, with the rationale underpinning a small-scale survey meant to gather data about teachers' views on reflective practice. It then moves on to present the results of this outlook. These voices from the field subsequently help identify which of these techniques are feasible candidates to an implementation as specialized widgets likely to transform a learning environment so that it can become supportive for meta-learning. Finally, a set-up for an experiment deemed to empirically ascertain the potential of widgets for reflection is outlined.

\section{The importance of teachers' voices}

Personal Learning Environments, widget technology, social software, all Web 2.0 artefacts are gaining momentum (Owen, 2007; S Wilson, 2008) and have even been designated as the future of education (Attwell, 2007; Jones, 2008). Whilst they hold out likelihood of enhanced flexibility, aggregation, inter-operability, personalisation, how they can be exploited in the concrete by today's educators is still a severe challenge as confirmed by observations both on the Web and in the literature.

\subsection{Widgets for education, really?}

In formal instruction contexts the use of Web 2.0 artefacts has not retained much attention so far. Even widgets that claim to have just a link with the realm of school are far less numerous than widgets conceived for other domains. A quick search, conducted on April 26, 2010 on Yahoo Widgets website (http://widgets.yahoo.com) with the keywords "school", "education" and "learning" returns respectively 19, 48 and 68 results while games, calendar, webcams, finance or news return 640, 106, 269, 91 and 829 results. Similar outcomes hold for Google gadgets (http://www.google.com/ig/directory ) and Apple Dashboard widgets (http://www.apple.com/downloads/dashboard/). A closer look shows that, from a qualitative viewpoint, many widgets retrieved for the three keywords (school, education, learning) are foreign to regular classroom or e-learning courses, to say nothing of the recalcitrant "Last day of school countdown" widget.

\subsection{Discussions saturated with technical concerns}

As for the academic literature and expertise, its main concern sticks to 
describing requirements and architecture or testing prototypes, all of which are usually highly technical and often impenetrable, if not incomprehensible, for the non-expert educator. For example, at the Mupple (Mashup Personal Learning Environments) workshop 2009 it turned out that only 3 out of the 14 accepted contributions (http://sunsite.informatik.rwth-aachen.de/Publications/CEUR-WS/Vol506) made a substantial effort to relate Web 2.0 tools to pedagogical core concerns and concepts (competence, metacognition). In the same vein, Wieringa and Heerkens (2004) conclude, in their analysis of a sample of submissions to international conferences on engineering, that most submitted papers present a solution and illustrate it with a problem, rather than search for a solution to a given problem class or to a clearly identified need coming from the field. In order to prevent a certain blindness to the conditions of acceptance and use in real-world formal instruction settings, discussions about widgets would benefit from being tuned to practitioners' expressed needs and interests.

\subsection{A glimpse into teachers' opinions}

This is why this preliminary investigation of the potential of widgets for reflection intentionally opens with the results to a questionnaire survey devoted to perceptions and practice of reflective learning. From there, some considerations about the use of widgets-based applications are proposed to researchers, developers, instructional designers, or any other professional concerned with the enhancement of reflective thinking for learning. This initial study on reflective practice in eLearning courses ought to be seen as the entry point to a larger investigation concerned with meta-learning practice in formal education and should be extended with further investigations.

\section{A survey on techniques for reflection}

\subsection{Aim of the survey}

The survey was carried out in order:

- to gain insight about the relevance of reflection in the eyes of instructors; 
Infusing reflective practice in eLearning courses - Can widgets help?

- to investigate the state of affairs of reflection amplifiers in Open Educational Resources (OERs) courses offered by the Open University in the Netherlands;

- to hook discussions about harnessing widgets technology to reflective practice onto data coming from practitioners;

- to take forward the understanding of one concrete way in which widgets could be used within online learning.

\subsection{Participants characteristics}

The survey was carried out amongst 22 creators of an eLearning course who partook in the Open Educational Resources (OpenER) project launched by the Open University in the Netherlands (Schuwer, 2008). The OpenER-project makes available a variety of higher education eLearning content free of charge. Like similar initiatives over the world (MIT OpenCourseWare, MERLOT, OPENLEARN, etc.), it targets an expansion of the higher education learning opportunities. The choice of Open Educational Resources (OERs) courses for the survey has three reasons. First, the Open University in the Netherlands has defined a program aimed at enhancing its offer of open educational resources. Second, the course creators are experienced developers of eLearning content. Third, the research was conducted in the context of the i-Coper project which is dedicated to open educational resources. Course creators were asked to fill in an electronic questionnaire regarding opportunities for reflection displayed in their courses. The survey set-up is presented below.

\subsection{Method}

In March 2009, 22 creators of an Open Educational Resources course of the Open University of the Netherlands received an invitation to an online questionnaire which presented the description of 35 existing techniques meant to amplify reflection, as reviewed and categorized (cf. Appendix for a short definition of each reflection amplifier and for a description of the categories) by Verpoorten, Westera, and Specht (2010). For each of these reflective techniques - called by the authors "reflection amplifiers" respondents were asked to tick one of the following options:

- I do not understand this technique.

- This technique is not relevant for my course. 
- This technique would be relevant for my course but is not implemented.

- This technique is implemented in my course.

This type of investigation was chosen in order to find what concrete reflective techniques are considered as relevant by e-learning course creators. The research was exclusively based on the answers given by participants. No reality check was done in the courses.

\subsection{Presentation of the data}

The exploratory and qualitative stance of the survey and its restricted sample size account for omitting advanced statistical calculations. Instead, the descriptive statistics provided should be regarded as rough indications likely to inform further research into widgets-supported reflective practice and to safeguard it from disconnection with practitioners' concerns.

\subsection{Results}

Overall, 13 course creators (cf. Figure 1) out of 22 completed the questionnaire. In view of the 35 techniques for reflection that were presented, this means that the study collected $455(13 \times 35)$ practitioners' qualifications over reflection amplifiers. Below, the aggregated outcomes are summarised.

\section{Understanding of the reflection amplifiers}

The reflection amplifiers seem to be well understood. Only 23 out of 455 answers "I do not understand this technique" were collected. Amplifiers the least understood by the 13 respondents, that is amplifiers for which the option "I do not understand this technique" has been the most often ticked, are Formative assessment (4/13), Structure for regulative support (3/13), On-demand assessment (3/13), Confidence-Based Learning (3/13).

\section{Relevance of specific reflection amplifiers}

Respondents, 75 times out of 455 , claim that a specific amplifier would be relevant for their course but is not implemented. Amplifiers with the most potential are: Help seeking behaviour guide (4/13), Graphical presentation of contents (4/13), Students set the test (4/13), Indicators of understanding (4/13). 
Infusing reflective practice in eLearning courses - Can widgets help?

\section{Overall relevance of reflection amplifiers}

When grouping the answer categories "This technique would be relevant for my course but is not implemented" and "This technique is implemented in my course" versus "This technique is not relevant for my course", it gives 157 claims of relevance versus 275 claims of nonrelevance. (The 23 "I do not understand this technique" are not taken into account). So, a large part of the reflection techniques are recognised as being of relevance for the eLearning courses.

\section{Existing practice}

According to respondents, 82 out of 455 reflection amplifiers are implemented in the courses. Highest occurrences: Making pedagogical rationale transparent (9), Metacognitive modelling (8), Self-explanations (6), Practice of evocation (4), Justify your choice (4), Graphical presentation of contents (4), Room for choice (4). Used amplifiers are unevenly spread in the courses (cf. Figure 1).

The small sample allowed for a "human-made" inspection of the data aiming at looking for patterns of aggregation of reflection amplifiers. No significant one could be identified, not even at the level of one-one combinations. It means that practitioners used very varied compounds of techniques.

\section{$<$ INSERT FIGURE 1 HERE $>$}

Focus on the exploitation of tracked data.

Several reflection amplifiers are based on the mirroring of personal tracked data. The study reveals that 7 out of 13 course creators don't know whether the eLearning platform on which they developed the course provides any tracking facility. Overall, 3 respondents state that they use tracked data as a teacher. Only 1 respondent says that the tracked data is used by the students. When asked whether they would give their students access to their learning traces as a reflection amplifier, 4 teachers out of 13 answer positively (cf. Figure 2).

\section{$<$ INSERT FIGURE 2 HERE $>$}

\subsection{Conclusion of this survey}


In sum, course creators express a fairly high rate of relevance regarding techniques for fostering reflection (157 out of 432). This may even be an underestimation because of the specific context of open educational resources. Yet, some of the respondents used the open comments section in the questionnaire to express practical disclaimers for not using reflection amplifiers: three respondents stressed that they had limited time and resources to devote to the design of the course. They also state that the request of the Open Educational Resources project was just striving for digital content in order to have a few courses available as soon as possible. Despite these adverse conditions, $35 \%$ of the reflection amplifiers submitted to the whole group are ticked as relevant.

Yet, the reported findings are based on a restricted sample. Since they are not representative for users in general, they need to be complemented by and compared with further evaluation data. Nevertheless, the outcomes of the study are able to provide first indications on users' opinion on widgetsbased reflection amplifiers and subsequently on the widgets capable to materialize them. Extrapolating from the survey, some recommendations are now made.

\section{Designing Widgets as reflection enablers}

A key assumption of this paper is that widgets technology can fruitfully be harnessed to the facilitation of a reflective approach to learning which, according to the results of the exploratory survey, sounds interesting to a portion of practitioners. Two coupled questions arise at this stage: which techniques of reflection can be reasonably "widgetized"? and why does widget technology especially seem relevant, compared to numerous educational research studies that have previously addressed the issue of promoting reflective skills with technologies? We tackle these questions in the next sections. Before starting, it is important to stress that the following observations must be seen as working hypotheses that require further refinement and testing. These verifications will be partly addressed in the experiment outlined in the last section.

\subsection{Candidates to "widgetisation"}

Teachers gave their opinion about 35 reflective techniques. Most of these techniques are too complex to be used as widgets, according to the definition given in the introduction ${ }^{1}$ which combines two features for widgets: a clear single task to execute and a very recognizable graphical style. Amongst others, these features can hardly hold for reflection techniques like "On-demand assessment", "Portfolios", "Students set the 
Infusing reflective practice in eLearning courses - Can widgets help?

test", "Help seeking behaviour guide", etc. However, a "widgetisation" matching both criteria seems possible for the following techniques:

a) Growing progress visualization tool: the widget would offer visual displays (e.g. progress sliders, understanding meters) enabling learners to determine their progress (actions and mastery) towards the learning goals. 3 respondents out of 13 consider this feature as relevant for their course;

b) Comparison with yardstick: the widget would specialise in comparing certain aspects of the learning process (time spent, exercises completed, estimation of knowledge, own performance, etc.) with some yardstick (teacher, peer, expert, classroom average, oneself in similar circumstances, compliance ratio, etc.). 7 respondents out of 13 consider this feature as relevant for their course;

c) Indicators of understanding: the widget would prompt learners to qualify their understanding of the course with simple indicators like "lost/not fully clear/got it" or some similar labels. 7 respondents out of 13 consider this feature as relevant for their course;

d) Judgement of learning: the widget would allow students to report the progress they believe they made in the learning domain or objectives as a consequence of doing the course. 7 respondents out of 13 consider this feature relevant for their course;

e) Self-efficacy judgments: the widget would engage students in selfassessments of their perceived level of knowledge or ability for a task. 7 respondents out of 13 consider this feature as relevant for their course;

f) Mirroring of personal tracked data: the widget would allow a visualisation by the learners of different interactions they had with the course. 3 respondents out of 13 consider this feature as relevant for their course.

When carefully examined, the above candidates to widgetization fall into two categories. The first one elicits reflection by visualizing personal tracked data $(a, f)$, possibly enriched with social data (b) used as a yardstick. The second induces reflection by offering to learners an opportunity to give a quick insight into their learning processes $(\mathrm{c}, \mathrm{d}, \mathrm{e})$ thanks to scoring/rating/ticking widgets. These categories are now further elaborated.

Category 1 - Widgets for the mirroring of interaction footprints

This category of widgets for reflection induces the reflective experience by requesting the learners to look at or ponder upon externally provided 
cues or information related to the learning context and the learners' positioning within it. Reflection amplifiers in this category do not imply any observable action of the learner, except, possibly, the time spent in the contemplation process. From the system perspective, this category most often demands that some personal data are tracked, recorded and shown. Coming back to the widget's definition favoured in this article, a distinct graphical interface can plausibly address the single task (looking at, pondering upon) requested by this type of reflective technique.

The survey delivers ambiguous answers regarding contemplation of personal tracked data as a lever for student's reflection. On the one hand, to have students pondering upon their interaction footprints is granted some potential by practitioners (cf. Figure 2). On the other hand, 7/13 course creators don't know whether their eLearning platform provides any tracking facility. They do not use the traces themselves and do not know whether students do. Several studies indicate that teachers (Mazza and Dimitrova, 2004; Scheuer and Zinn, 2007; Jovanović, 2008), students (Johnson and Sherlock, 2008) and learners (Glahn, 2009) can reap metalearning benefits from the observation of learning traces. Making this data available through specialised tracking and tracing widgets is likely to boost the extent of this practice. It implies to establish links between tracking and tracing facilities and specialised tracking and tracing widgets. From an application point of view, such widgets would remain single objects but their semantics, visual appearance, dependencies and overall development can become very complex and demanding, as already observed in an early article on the topic (Swick and Ackerman, 1988, p. $3)$.

\section{Category 2 - Widgets for student-driven evaluation}

This category of widgets for reflection induces the reflective experience by asking the learners to give a quick insight into their behaviours or performances through the use of a scale. From the system perspective, this category requests the presentation of scoring/rating/ticking artefacts to the learner. Students commenting on their work during the work-in-progress is actually a promising trend in reflective practice. It is different from techniques like portfolios or learning diaries in that student's comments are produced simultaneously within the learning process in order to give insight into mental process and into the meaning of the work while performing it.

Once developed and embedded in the courses, specialized widgets from both categories would represent self-contained meta-learning activities. 
Infusing reflective practice in eLearning courses - Can widgets help?

Each of them could be formalised, following a suggestion by Moedritscher and Wild (2009, p. 3), as a triplet, of:

- at least one tool. Example: "I use the widget "Understanding indicators";

- an action. Example: "With the widget, I rate my understanding of this content";

- an outcome. Example: "Thanks to this widget, and through the clear, small and single action it allows, I train my meta-learning skill for self-assessment".

Borders between the two categories are not rigid. Yet, they can be combined and mutually supportive. For instance, a student can be asked to rate his progressive mastery of a content while studying. And a postpractice reflective activity can consist in commenting this progression based on the mirroring of his successive evaluations.

\subsection{Reasons to give a trial to widgets for reflection}

This section elaborates on reasons why widgets technology is considered particularly relevant for infusion of opportunities for reflection in distance education. Again, this rationale must be considered as tentative and mainly used for the derivation of hypothesis for further improvement in the research cycle concerned with the enhancement of reflective thinking and with the implementation of subservient technologies.

\section{Reason 1 - Contextualisation of reflection}

Literature on reflection demonstrates the importance of training thinking skills in the context of learning and not in separate courses and trainings (Resnick and Klopfer, 1989). From this request ensues the need to closely relate opportunities for reflection with the learning task they bear on. Embedding reflection amplifiers at different levels of a course conveys a renewed challenge both for pedagogy and for technology. Due to their small size and to their agility, widgets seem to be a technique worth investigating for an increased contextualisation of student's reflection. In this respect, the new possibilities to insert - through the Wookie server (Wilson, 2008) - widgets, and possibly widgets for reflection, within a learning design conceived with the Recourse IMS-LD authoring tool is a move in that direction. Real scenarios should be tested in order to document this nesting of widget-based reflective activities within concrete courses. The capacity of widgets to isolate, both graphically and 
cognitively, specific reflective actions also yields opportunities for research on self-monitoring, awareness and data mirroring issues.

\section{Reason 2 - Cockpits for learning}

At the opposite side of the widget capacity to isolate specific actions, the possibility to aggregate widgets is possibly a second added value of this technology. Personal Learning Environments and mash-ups form a new type of interfaces that were mostly investigated in informal learning contexts up to now. An aggregated use of widgets, selected by teachers and/or by learners, to compose "learning dashboards" as a support of formal learning is a potential still to be studied. Hence, it may be possible to conceive learning dashboards as contextual collections of widgets for reflection. Reflection would take place at the single widgets level but the dashboard itself would be a source of reflection at an upper level.

Different configurations of widgets for reflection might help building appropriate learning dashboards. The main characteristic of this new breed of interface would be a systematic criss-cross of information about content and information about the learner's position towards this content. Such a mix of external and personal information may pave the way for a renewed vision on personalised learning (Verpoorten \& al., 2009).

\section{Reason 3 - Pick-and-mix and progressive approach}

No single outstanding reflection amplifier emerges from faculty's answers and no preferred combination either. It means that teachers can just pick out one or several techniques as relevant (cf. Figure 1). The modular approach conveyed by widget technology, and more broadly by Web 2.0, seems quite suitable to cater for these variations. An individual teacher could select and aggregate (or not) widgets for reflection according to the courses, the student's needs or the level of reflection to be pursued. In such a pick-and-mix approach, inclusion of opportunities for reflection, within the framework of regular instruction might be tailored and progressive. Moreover, it is plausible that such a widget-driven evolution of already existing courses is more conceivable and possibly cheaper than introducing new courses, though cost-effectiveness evaluation should be part of the research agenda. Also, when applying these tiny and not much disruptive appliances, users (teachers, learners) are shielded against the need of dropping the existing Virtual Learning Environments and having to get acquainted with a completely new system. Furthermore, it is doubtful that long-term benefits from reflection can be expected from one or even a few reflection exercises. A work with reflection must probably 
Infusing reflective practice in eLearning courses - Can widgets help?

be arranged on a longer period and throughout different courses. The agile nature of widgets for reflection might ease this deployment and concur to the acquisition of reflective habits. The survey also suggests that research on widgets has a value on its own and does not need to be tightly coupled with research into Personal Learning Environments. eLearning courses can be relevant containers for isolated widgets.

\section{Reason 4 - Instant opportunities for reflection}

The last line of reasoning suggesting that widgets might be particularly useful in promoting reflection is related to learning culture. An objection of teachers to the implementation of reflection amplifiers can be that reflection takes time and that the course coverage might suffer from an allocation of efforts to reflection. This thought might be reinforced by a common association of reflection to portfolio or post-practice reflective activities mobilizing students. Widgetized reflection amplifiers, like the ones identified in section 4.1, might demonstrate that brief incitations to reflect on learning while learning can fruitfully be applied without requesting much time.

\section{A suggested experimental set-up}

Widgets for reflection should now be transformed into proper examples. In this respect, the authors are currently creating an eLearning course prototype enriched with concrete examples of widgets for reflection. This testbed is meant to provide a convenient context for research on conditions of use, impact and possible drawbacks and benefits of these pedagogically and technologically innovative learning tools. In the mock-up given hereafter (cf. Figure 3), some of the reflective techniques reviewed by Verpoorten, Westera and Specht (Verpoorten, Westera, and Specht, 2010), praised by teachers in the above study (cf. section 3 ) and considered as natural candidates to "widgetization" (cf. section 4) according to the definition (cf. section 1), can be seen:

- Mirroring of personal tracked data: this widget triggers reflection about self-monitoring by retroacting to the learner the number of actions he performed in the course so far;

- Indicators of understanding: this widget triggers reflection by requesting from the learner to rate his mastery of the resource he has just read. (This widget for reflection based on a self-reported measure 
could be applied to "judgment of learning" or "self-efficacy

judgments" (see appendix for definitions) or other meta-learning process worth for the student to become aware of);

- Comparison with yardstick might enrich the information provided by the previous widgets by contrasting actions in the course or selfreported understanding with peers/teacher/expert comparative values.

\section{<INSERT FIGURE 3 HERE $>$}

On the development side, it is planned to study technical feasibility and possibilities of truly smooth integration with the online course. On the pedagogical side, acceptability of and familiarity conditions with widgets for reflection will be investigated by observing their mandatory and/or voluntary use by learners in the course designed for the experimentation. Effects of different types of widgets for reflection will also be assessed.

\section{Conclusion}

Looking at reflection as a desirable educational goal induces the quest for instruments that are likely to foster it. This article considered the possibility of harnessing the agility of widgets to the training of thinking skills, within the framework of subject matter instruction. Based on literature, an inventory of 35 reflection techniques and a small-scale survey amongst teachers, it was argued that the development of widgets for reflection is a promising means to the infusion of certain types of reflective practice in eLearning courses. Due to its specific features agility, interoperability, self-contained activities, aggregation powerwidgets technology seems especially appropriate:

- to increase opportunities for instant and focused reflection within a particular learning task;

- to support an extended training of auto-cognitive skills (awareness during study, self-assessment, presence-to-learning) by embedding widgets for reflection within a variety of courses and systems;

- to provide teachers with ready-to-use reflective tools likely to be seamlessly activated according to the configuration they find the most pedagogically relevant;

- to facilitate cognitive regulation of personal learning by providing coordinated access to a variety of personal tracked data. 
Infusing reflective practice in eLearning courses - Can widgets help?

Through experimental setups, it is planned to explore effects of various displays, groupings, sequencing, and coordination of reflective tools on different dimensions of the instructional design and learning processes. If the experiments carried out in this particular environment delivers evidence of instructional benefits that buttress the interest expressed by teachers, issues related to the interoperability of the useful widgets in various learning environments will be addressed.

\section{References}

Attwell, G. (2007). Personal Learning Environments - the future of eLearning? eLearning Papers, 2(1).

Carnell, E. (2005) 'Understanding and enriching young people's learning: issues, complexities and challenges'. Improving Schools, 8, pp. 269-84.

Claxton, G. (2006) 'Expanding the Capacity to Learn: A new end for education?' Keynote speech presented at the British Educational Research Association Annual Conference. September, 6-9, 2005. University of Warwick, UK.

Csapó, B. (1999) 'Improving thinking through the content of teaching', In Hamers, H, van Luit $\mathrm{J}$, and Csapó, B. (eds.), Teaching and learning thinking skills (pp. 37-62), Lisse: Swets and Zeitlinger.

Diagne, F. (2009) Instrumentation de la supervision de l'apprentissage par la réutilisation d'indicateurs: Modèles et Architecture. PhD thesis. Université Joseph Fourier, Grenoble, France.

Glahn, C. (2009) Contextual support of social engagement and reflection on the Web. PhD thesis. Open University of the Netherlands, Heerlen, Netherlands.

Glahn, C., Specht, M., \& Koper, R. (2007) 'Smart indicators on learning interactions'. In Duval, E., Klamma, R. and Wolpers, M. (eds.), EC-TEL 2007 LNCS 4753 (pp. 56-70), Berlin, Heidelberg: Springer.

Gui Widget. (2009) Obtained through the Internet: http://en.wikipedia.org/wiki/GUI_widget, [accessed 03/1/2010].

Hattie, J. (2009) Visible Learning: A Synthesis of over 800 Meta-Analyses Relating to Achievement. London: Routledge.

Johnson, M. and Sherlock, D. (2008) 'Personal Transparency and selfanalytic tools for online Habits'. Paper presented at the TenCompetence Workshop "Stimulating Personal Development and Knowledge Sharing”. October 30-31, 2008. Sofia, Bulgaria.

Jovanović, J. (2008) 'Generating context-related feedback for teachers', Int. J. Technology Enhanced Learning, Vol. 1, Nos. 1/2, pp.47-69. 
Marzano, R. J. (1998) A theory-based meta-analysis of research on instruction. Aurora, CO: Mid-continent Regional Educational Laboratory.

Mazza, R., and Dimitrova, V. (2004) 'Visualising student tracking data to support instructors in web-based distance education'. Paper presented at the13th international World Wide Web conference on Alternate track papers and posters, May 17-22, 2004. New York, USA.

Moedritscher, F., and Wild, F. (2009). 'Why not Empowering Knowledge Workers and Lifelong Learners to Develop their own Environments?' Paper presented at the I-Know Conference, September 2-4. Graz, Austria.

Resnick, L., and Klopfer, L., eds., (1989) Toward the Thinking Curriculum: Current Cognitive Research. Alexandria, VA: ASCD.

Scheuer, O., and Zinn, K. (2007) 'How did the e-learning session go? The Student Inspector'. Paper presented at the 13th International Conference on Artificial Intelligence in Education, July 9-13. Los Angeles, USA.

Schön, D. (1983) The Reflective Practitioner: How professionals think in action. London: Temple Smith.

Schuwer, R. (2008) Zicht op OpenER Resultaten en effecten van een experiment met Open Educational Resources: Open University Netherlands. Obtained through the Internet: http://blog.opener.ou.n1/wpcontent/uploads/2008/09/rapport_opene r_def.pdf, [accessed 03/1/2010].

Swick, $\bar{R}$., and Ackerman, M. (1988) 'The X Toolkit: More Bricks for Building User Interfaces, or Widgets for Hire'. Paper presented at the Usenix Winter 1988 Conference. January. Dallas, Texas, USA.

Verpoorten, D., Westera, W., and Specht, M. (2010) 'Reflection amplifiers in online courses: a classification framework'. Journal of Interactive Learning Research, 21(4).

Verpoorten, D., Glahn, C., Kravcik, M., Ternier, S., and Specht, M. (2009) 'Concepts for Personalising of Learning in Virtual Learning Environments'. Paper presented at the ECTEL conference. September 29 - October 2, 2009. Nice, France.

Wang, M., Haertel, G., and Walberg, H. (1990) 'What Influences Learning? A Content Analysis of Review Literature'. Journal of Educational Research, 84, pp. 30-43.

Watkins, C. (2001) Learning about Learning Enhances Performance. London: Institute of Education, University of London.

Wieringa R.J., and Heerkens, H. (2004) 'Evaluating the structure of research papers: a case study'. In Gervasi V, Zowghi D, Sim SE (eds.), Second international workshop in comparative evaluation 
Infusing reflective practice in eLearning courses - Can widgets help?

of requirements engineering.

Wilson, S. (2008) Wookie Widget Developer's Guide. Obtained through the

Internet:

http://getwookie.org/Widgets_files/widget_dev_guide.pdf, [accessed 03/1/2010].

1. It is not excluded that changes in the technology may make a different definition appropriate (such an evolution of definition can be observed, for instance, with learning objects) or that advanced widget-like techniques could address these complex techniques or complement them (it could, for example, be the case with smart indicators (Diagne, 2009; C. Glahn, Specht, and Koper, 2007).

\section{Number of reflection amplifiers per course}

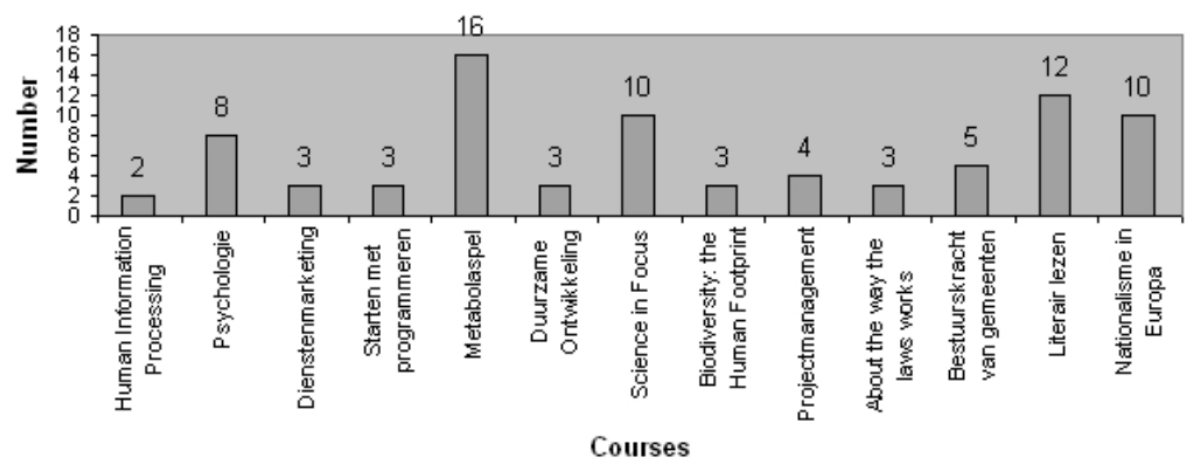

Figure 1. The number (and combinations) of reflection amplifiers greatly varies among courses.

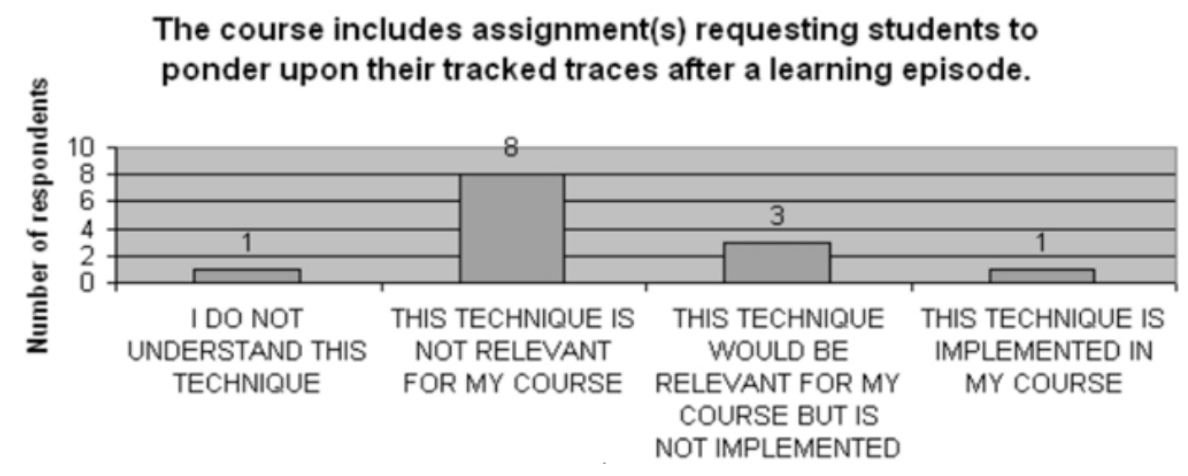

Figure 2. Teachers' allotment regarding the exploitation of student's personal tracked data as a lever for reflection. 


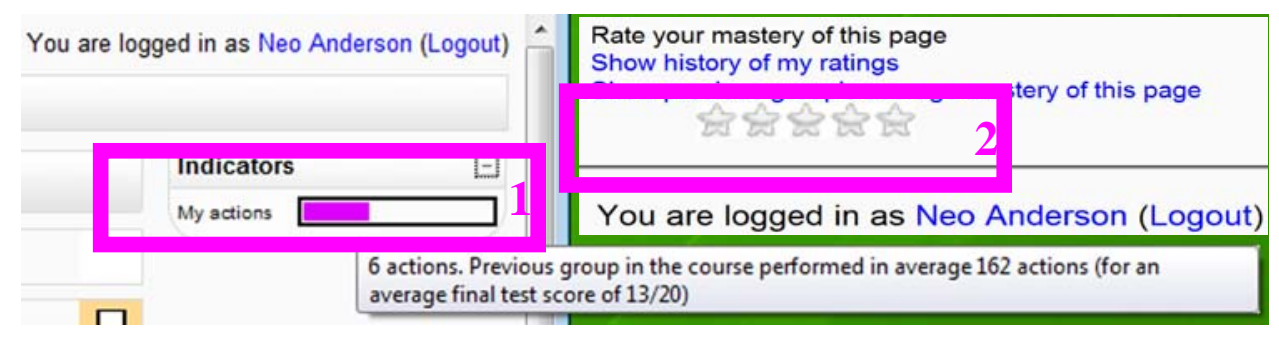

Figure 3. In this mock-up, reflection is triggered by widgets mirroring personal tracked data (here: number of actions performed in the course) or asking the learner to rate his current perceived level of mastery.

\section{Appendix}

The questionnaire survey reported in this paper presented to higher education teachers 35 reflective techniques found in the literature (Verpoorten et al., 2010). In the tables below, the reflection amplifiers are provided with a textual label, and explained with an extremely compact definition. As for literature references related to each reflection amplifier, see the original article. For practical reasons (size) the reflection amplifiers are clustered into separate tables according the type of interaction involved (receiving information/giving information/verbalizing information). Greyed boxes contain the reflection amplifiers that we considered as the most suited candidate to "widgetization" (cf. Section 3.2) and, consequently, as the most likely candidate for the experimental study outlined in section 4 . The authors operate their classification according to an input/output scheme. The inputs of the process are conceived as the various modes of interaction that occur when the learner is confronted with a reflection amplifier. The outputs of the process essentially correspond with the particular objectives that are pursued by the reflection amplifier, that is the skills involved and trained. In the article, the authors do not deny that reflection amplifiers could be reclassified in some other ways, for instance according to the line of inquiry they come from (self-regulated learning, meta-cognition, learning to learn), the level of complexity of their implementation, or their location in the learning process (before the action, during the action, after the action). However, the authors specify that the two final clustering keys are consistent with the aforementioned motives to undertake this research: (a) tackling pedagogical concerns: rows are centred on the training of reflective abilities; (b) taking into account the multimedia aspects of reflection amplifiers: columns relate to the interactions learners have with the instruments. The principal dimensions realise a connection between the how (input) and the why (objectives) of the reflection process. It is 
however true that administering the survey to a much larger representative sample could be a further step in the consolidation of the classification framework. With the data so collected, factor analysis could be conducted to identify any emerging aggregates.

Table A1. Reflection amplifiers enacted by receiving information

\begin{tabular}{|c|c|c|}
\hline & Label & Description \\
\hline 1 & $\begin{array}{l}\text { Transparent } \\
\text { pedagogical } \\
\text { rationale }\end{array}$ & $\begin{array}{l}\text { The learners get informed about why this } \\
\text { learning activity has been designed for them } \\
\text { and how completing it will affect them. }\end{array}$ \\
\hline 2 & $\begin{array}{l}\text { Objectives/criteria } \\
\text { of a task }\end{array}$ & $\begin{array}{l}\text { The learners are periodically reminded of the } \\
\text { conditions under which they will succeed. }\end{array}$ \\
\hline 3 & Room for choice & $\begin{array}{l}\text { The course gives opportunities to choose } \\
\text { learning activities (order, number, type) } \\
\text { according to interest or learning needs. }\end{array}$ \\
\hline 4 & $\begin{array}{l}\text { Annotation sharing } \\
\text { mechanisms }\end{array}$ & $\begin{array}{l}\text { The annotations (reflections on the material, } \\
\text { notes, summaries...) a learner adds to learning } \\
\text { materials are made available to other learners. }\end{array}$ \\
\hline 5 & $\begin{array}{l}\text { Graphical } \\
\text { presentation of } \\
\text { contents }\end{array}$ & $\begin{array}{l}\text { Graphic organizers are presented as alternative } \\
\text { or complement to textual structure: mind- } \\
\text { maps, heuristic schemas, spider webs, } \\
\text { contrast matrices, etc. }\end{array}$ \\
\hline 6 & $\begin{array}{l}\text { Structure for } \\
\text { regulative support }\end{array}$ & $\begin{array}{l}\text { The course includes a "dashboard", viz. a page } \\
\text { that bundles personal indicators allowing the } \\
\text { learners to keep an updated status of their } \\
\text { situation in the course and to better control it. }\end{array}$ \\
\hline 7 & $\begin{array}{l}\text { Growing progress } \\
\text { visualization tool }\end{array}$ & $\begin{array}{l}\text { Visual displays (progress sliders, } \\
\text { understanding meters, etc.) enabling the } \\
\text { learners to determine their progress (actions } \\
\text { and mastery) towards the learning goals. }\end{array}$ \\
\hline 8 & $\begin{array}{l}\text { Mirroring of } \\
\text { personal tracked } \\
\text { data }\end{array}$ & $\begin{array}{l}\text { Different kinds of learner interactions with the } \\
\text { course are tracked and recorded to make } \\
\text { personal traces available. }\end{array}$ \\
\hline 9 & $\begin{array}{l}\text { Meta-cognitive } \\
\text { modelling }\end{array}$ & $\begin{array}{l}\text { The teacher or a subject-matter expert displays } \\
\text { modelling behaviour, showing how to think } \\
\text { about the material (knowledge, skills, } \\
\text { procedures, etc.) }\end{array}$ \\
\hline 10 & $\begin{array}{l}\text { Help seeking } \\
\text { behaviour guide }\end{array}$ & $\begin{array}{l}\text { The course provides guidelines for using help } \\
\text { at the right moment. }\end{array}$ \\
\hline 11 & $\begin{array}{l}\text { Comparison with } \\
\text { yardstick }\end{array}$ & $\begin{array}{l}\text { Learners get opportunities for comparing } \\
\text { aspects of their learning experience (time } \\
\text { spent, exercises completed, estimation of }\end{array}$ \\
\hline
\end{tabular}




\begin{tabular}{|l|l|l|}
\hline & & $\begin{array}{l}\text { knowledge, own performance...) to some } \\
\text { external yardstick (teacher, peer, expert, } \\
\text { classroom average, oneself in similar } \\
\text { circumstances, compliance ratio, etc.). }\end{array}$ \\
\hline 12 & $\begin{array}{l}\text { Records of } \\
\text { marks/remarks }\end{array}$ & $\begin{array}{l}\text { The marks and the remarks received from the } \\
\text { instructor(s) are stored and can be consulted } \\
\text { by the student. }\end{array}$ \\
\hline
\end{tabular}

Table A2. Reflection amplifiers enacted by giving information

\begin{tabular}{|c|c|c|}
\hline & Label & Description \\
\hline 13 & $\begin{array}{l}\text { Enhanced } \\
\text { Multiple Choice } \\
\text { Question }\end{array}$ & $\begin{array}{l}\text { Learners answer enriched Multiple Choice } \\
\text { Questions. The proposed answers include meta- } \\
\text { level options like "All answers correct", "None } \\
\text { of the answers correct", "The question is } \\
\text { absurd", "The terms of the problem are too ill- } \\
\text { defined for giving a correct answer", etc. }\end{array}$ \\
\hline 14 & $\begin{array}{l}\text { Ease-of- } \\
\text { learning/self- } \\
\text { efficacy } \\
\text { judgments }\end{array}$ & $\begin{array}{l}\text { The learners engage in a self-assessment of their } \\
\text { perceived ability for the task. }\end{array}$ \\
\hline 15 & $\begin{array}{l}\text { Indicators of } \\
\text { understanding }\end{array}$ & $\begin{array}{l}\text { Learners are asked to qualify their understanding } \\
\text { with simple indicators like "lost/not fully } \\
\text { clear/got it" or equivalent. }\end{array}$ \\
\hline 16 & $\begin{array}{l}\text { Formative } \\
\text { assessment }\end{array}$ & $\begin{array}{l}\text { The course offers assessment intended to } \\
\text { generate feedback on performance to improve, } \\
\text { helping learners to assess their own learning. }\end{array}$ \\
\hline 17 & $\begin{array}{l}\text { Interruptive } \\
\text { monitoring }\end{array}$ & $\begin{array}{l}\text { Periodically on-the-fly questions appear about } \\
\text { perceived performance. Learners provide a score } \\
\text { on an appropriate scale. }\end{array}$ \\
\hline 18 & $\begin{array}{l}\text { On-demand } \\
\text { assessment }\end{array}$ & $\begin{array}{l}\text { Learners can summon the examination when } \\
\text { they feel that their mastery is sufficient. }\end{array}$ \\
\hline 19 & $\begin{array}{l}\text { Choosing the } \\
\text { difficulty of } \\
\text { questions }\end{array}$ & $\begin{array}{l}\text { In the course, the learners can request easier or } \\
\text { harder questions. }\end{array}$ \\
\hline 20 & $\begin{array}{l}\text { Confidence- } \\
\text { Based Learning }\end{array}$ & $\begin{array}{l}\text { Learners are asked to answer questions and } \\
\text { express their confidence in the correctness of } \\
\text { their answers. }\end{array}$ \\
\hline 21 & $\begin{array}{l}\text { Profiling } \\
\text { questionnaire }\end{array}$ & $\begin{array}{l}\text { The course encourages learners to reflect about } \\
\text { themselves by filling in a learning profile } \\
\text { questionnaire. }\end{array}$ \\
\hline 22 & Judgment of & Learners are asked to report the progress they \\
\hline
\end{tabular}


Infusing reflective practice in eLearning courses - Can widgets help?

\begin{tabular}{|l|l|l|}
\hline learning & $\begin{array}{l}\text { believe they made in the learning area as a } \\
\text { consequence of having taken the course. }\end{array}$ \\
\hline
\end{tabular}

Table A3. Reflection amplifiers enacted by verbalizing information

\begin{tabular}{|c|c|c|}
\hline & Label & Description \\
\hline 23 & $\begin{array}{l}\text { Where and } \\
\text { Why Is It } \\
\text { Wrong? }\end{array}$ & $\begin{array}{l}\text { Learners receive pieces of work for which they } \\
\text { are asked to say what is wrong and why. }\end{array}$ \\
\hline 24 & $\begin{array}{l}\text { Students set the } \\
\text { test }\end{array}$ & $\begin{array}{l}\text { Learners are asked to make up the questions they } \\
\text { could get for their exam. }\end{array}$ \\
\hline 25 & $\begin{array}{l}\text { Writing on the } \\
\text { reading }\end{array}$ & $\begin{array}{l}\text { The course provides annotation tool(s) along with } \\
\text { the electronic learning material. }\end{array}$ \\
\hline 26 & $\begin{array}{l}\text { Practice of } \\
\text { evocation } \\
\text { (pausing to } \\
\text { reflect) }\end{array}$ & $\begin{array}{l}\text { Learners are requested to recall important or } \\
\text { puzzling facts/ideas/concepts from the previous } \\
\text { learning episode. }\end{array}$ \\
\hline 27 & $\begin{array}{l}\text { Questions } \\
\text { generation }\end{array}$ & $\begin{array}{l}\text { Learners are invited to post questions about the } \\
\text { material for which they receive a feedback. }\end{array}$ \\
\hline 28 & $\begin{array}{l}\text { Self- } \\
\text { explanations }\end{array}$ & $\begin{array}{l}\text { The course trains the learners to generate } \\
\text { explanations about the content of an exercise, a } \\
\text { strategy, a text, a learning goal, an example, etc. }\end{array}$ \\
\hline 29 & $\begin{array}{l}\text { Justify your } \\
\text { choice }\end{array}$ & $\begin{array}{l}\text { Learners are asked to justify choices they made in } \\
\text { the course. }\end{array}$ \\
\hline 30 & $\begin{array}{l}\text { Eliciting } \\
\text { intentions } \\
\text { before a task }\end{array}$ & $\begin{array}{l}\text { The course makes room for the learners to reflect } \\
\text { about how to handle the task and their } \\
\text { expectations to encounter any problems through } \\
\text { it. }\end{array}$ \\
\hline 31 & $\begin{array}{l}\text { Comment on } \\
\text { "learning } \\
\text { footprints" }\end{array}$ & $\begin{array}{l}\text { The course includes assignment(s) requesting } \\
\text { learners to ponder upon their tracked traces after a } \\
\text { learning episode. }\end{array}$ \\
\hline 32 & $\begin{array}{l}\text { Permanent } \\
\text { reflecting tools }\end{array}$ & $\begin{array}{l}\text { The course asks learners to verbalize and record } \\
\text { their thinking activities related to learning tasks in } \\
\text { a learning diary or a similar tool (e.g. blog, } \\
\text { portfolio) }\end{array}$ \\
\hline 33 & $\begin{array}{l}\text { Explicit } \\
\text { reflective } \\
\text { activities }\end{array}$ & $\begin{array}{l}\text { The course includes self-reflective activities } \\
\text { encouraging students to analyse various aspects of } \\
\text { their performance. }\end{array}$ \\
\hline 34 & $\begin{array}{l}\text { Comments on } \\
\text { Comments }\end{array}$ & $\begin{array}{l}\text { The learner is asked to write a comment in } \\
\text { response to the instructor's comments. }\end{array}$ \\
\hline 35 & Test debriefing & $\begin{array}{l}\text { Learners are formally invited to question their } \\
\text { own results and to analyse successes/failures, } \\
\text { strengths/weaknesses, areas to review, errors or }\end{array}$ \\
\hline
\end{tabular}


misconceptions. 